\title{
Kajian Kualitas Fisik Ransum Pelet dalam Upaya Rekayasa Ransum Bagi Kuskus Bertotol Biasa
}

\section{Study of the Physical Quality of Pelet Ration as an Effort to Modify Rations for Common Spotted Cuscus}

\author{
M. Kayadoe ${ }^{1,2}$, S. Sinaga ${ }^{3}$, A. Rochana ${ }^{3}$, dan U. H. Tanuwiria ${ }^{3}$ \\ ${ }^{1}$ Animal Husbandry Posgraduate Program, Faculty of Animal Husbandry, Universitas Padjadjaran, \\ Jatinangor. 45363, West Java, Indonesia \\ ${ }^{2}$ Laboratory of Nutrition and Feed Science, Faculty of Animal Science, University of Papua, 98314 \\ Manokwari, West Papua, Indonesia. \\ ${ }^{3}$ Faculty of Animal Husbandry, Universitas Padjadjaran, Jatinangor. 45363, West Java, Indonesia \\ ${ }^{1}$ Corresponding Author: marthakayadoe837@gmail.com
}

\begin{abstract}
Fresh feed for cuscus has been carried out, however, the fresh feed has a fast rate of damage, so it is necessary to study the feedthrough further processing in the form of pellet rations which are the result of the formulation of cuscus feed ingredients. As a follow-up, it is necessary to study the physical quality of pellet rations. The formulation of pellet rations was based on the study of preferred level of seven types of cuscus feed (banana, sweet starfruit, matoa leaves, beach ironwood leaves, water spinach leaves, green mustard leaves, and crickets) that are useful as a source of carbohydrates, fiber sources, protein sources of vegetable a protein source of animal. The treatments consisted of three formulations: formulation A based on preference level, formulation B by increasing protein content $10 \%$ and formulation $\mathrm{C}$ increased protein $20 \%$ of requirement. Each formulation was made of two types of pellet diameter, $5 \mathrm{~mm}$ and $7 \mathrm{~mm}$, so that pellet rations treatment was obtained. The physical quality test included water content, water activity, pellet and mesh density using analysis of variance, while tests of resistance to friction and resistance to impact were analyzed descriptively. The results showed that the pellet ration with formulation A had better physical quality both with a diameter of $5 \mathrm{~mm}$ and $7 \mathrm{~mm}$, but overall from the three formulations concluded that the best $5 \mathrm{~mm}$ diameter of a pellet.
\end{abstract}

Key words : ration, cuscus, pellet diameter, physical quality.

\begin{abstract}
ABSTRAK
Kajian pakan segar untuk kuskus telah dilakukan, namun pakan segar memiliki tingkat kerusakan yang cepat, sehingga perlu dilakukan kajian terhadap pakan tersebut melalui pengolahan lebih lanjut berupa ransum pelet yang merupakan hasil formulasi bahan-bahan pakan kuskus. Sebagai tindak lanjutnya perlu kajian terhadap kualitas fisik ransum pelet tersebut. Formulasi ransum pelet didasari dari kajian tingkat kesukaan terhadap 7 jenis pakan kuskus (pisang mas, belimbing manis, daun matoa, daun kayu besi pantai, daun kangkung, daun sawi hijau dan jangkrik) yang bermanfaat sebagai sumber karbohidrat, sumber serat, sumber protein nabati dan sumber protein hewani. Perlakuan terdiri dari 3 formulasi : formulasi A berdasar tingkat kesukaan, formulasi B dengan meningkatkan kadar protein $10 \%$ dan formulasi C ditingkatkan protein $20 \%$ dari kebutuhan melalui perhitungan Microsoft excel. Setiap formulasi dibuat 2 tipe ukuran diameter pelet yaitu $5 \mathrm{~mm}$ dan $7 \mathrm{~mm}$, sehingga diperoleh 6 perlakuan ransum pelet. Uji kualitas fisik meliputi kadar air, aktivitas air, densitas pelet dan densitas mesh menggunakan analisis sidik ragam, sedangkan uji ketahanan terhadap gesekan dan ketahan terhadap benturan dianalisis secara deskriptif. Hasil penelitian menunjukkan bahwa ransum pelet dengan formulasi A memiliki kualitas fisik lebih baik dengan diameter $5 \mathrm{~mm}$ maupun $7 \mathrm{~mm}$. Namun secara keseluruhan dari ketiga formulasi diperoleh kesimpulan bahwa diameter $5 \mathrm{~mm}$ yang terbaik.
\end{abstract}

Kata kunci : ransum, kuskus, diameter pelet, kualitas fisik.

\section{PENDAHULUAN}

Kuskus merupakan salah satu satwa yang hidup dalam kawasan alam Papua selain beberapa satwa lainnya. Potensi yang menjadi keistimewaan kuskus adalah keindahan warna bulunya yang mencirikan spesies kuskus. Kuskus bertotol biasa sebagai salah satu spesies yang ada diantara spesies kuskus bertotol lainnya (Flannery, 1994; Sinery et al., 2013; Wibisono et al. 2018). Spesies kuskus bertotol dalam kawasan Papua tersebar di beberapa kepulauan yaitu di Yapen, Biak Numfor, 
Moor, Misol, Batanta, Waigeo dan Salawati (Sinery, 2015).

Kuskus dalam kawasan hutan Papua telah memanfaatkan potensi yang ada di sekitarnya sebagai sumber pakan demi keberlangsungan hidupnya. Buah-buahan dan pucuk-pucuk daun tumbuhan hutan maupun tumbuhan perkebunan dipilih oleh kuskus sebagai bahan pakannya (Sinery et al., 2013). Hasil kajian yang dilaporkan Kartikasari et al. (2013) didapat ada 15000 - 20000 spesies tumbuhan endemik Papua, sehingga banyaknya keragaman tersebut berpeluang untuk dimanfaatkan oleh kuskus dan satwa liar lainnya. Kuskus dan satwa liar lainya memanfaatkan tumbuhan untuk mencukupi keperluan hidup pokok, berkembang biak dan berproduksi.

Dalam habitat asli, kuskus memanfaatkan tumbuhan hutan dan perkebunan sebagai sumber pakannya diantaranya : Pometia pinnata, Pongamia pinnata, Coscos nusifera, Canarium modicum (Dahrudin et al., 2005), Pometia coreceae, Spondias dulcis dan Musa achisocarpa (Nakoh et al., 2010) dan sembilan spesies lainnya dalam kawasan hutan Sewan (Sarmi) di Papua (Kabelen dan Warpur, 2009) Berdasar 57 jenis tumbuhan yang dilaporkan Dahrudin et al. (2005) diketahui ada 41 spesies dimanfaatkan buahnya sebagai bahan pakan kuskus, sedangkan lainnya dalam bentuk daun, bunga, dan campuran antara buah, daun dan bunga dan bagian kulit dari tumbuhan tersebut. Sama halnya dengan yang terdapat di kawasan Udopi sebagian besar mengkonsumsi buah sebagai pakan yang paling disukai kuskus (Nakoh et al., 2010).

Hasil kajian pakan kuskus dalam penangkaran terdapat juga beberapa bahan pakan yang disukai kuskus. Jenis buahbuahan dan daun-daunan mendominasi dalam pemberian pakan untuk kuskus di penangkaran. Penangkaran di LIPI Cibinong (Farida et al., 2004) ternyata kuskus mengonsumsi pisang, markisa, jambu air, jambu biji, daun ketapang, daun pohpohan, kangkung dan daun kayu besi serta pakan sumber karbohidrat berupa roti, umbian, sedangkan di Retewi Nabire (Saragih et al., 2010) memperlihatkan kuskus diberi pisang, belimbing, papaya, kedondong dan kelapa selain daun kayu besi dan sumber karbohidrat berupa sagu dan nasi serta sumber protein berupa ikan. Hasil kajian di Unipa Manokwari (Kayadoe et al., 2015) diperoleh hasil kuskus menyukai buah pisang dan belimbing manis dibanding buah-buahan lainnya (nangka, papaya, advokat), sedangkan jenis daun yang disukai yaitu daun matoa dan daun kayu besi pantai, daun kangkung dan daun sawi dibanding daun kayu besi gunung dan daun ubi jalar. Pada satwaliar lainnya telah dikaji tingkat kesukaan kukang (Sinaga et al., 2010) dan tarsius (Farida et al., 2008) terhadap jangkrik (Sinaga et al., 2010) dibanding sumber protein lainnya. Oleh karena itu dapat diperkirakan bahwa satwaliar termasuk kuskus dapat diberikan sumber protein hewani berupa jangkrik selain pakan basal pisang dan daun. Hasil kajian Kayadoe et al. (2014) diketahui bahan pakan kuskus mengandung komponen kimia dan serat yang menjamin dapat dimanfaatkan kuskus.

Berdasarkan dari tingkat ketahanan atau daya awet bahan pakan ternyata perlu mendapat perhatian. Pakan untuk ternak termasuk kuskus perlu dipertimbangkan keefisienan dan keefektifan dalam penyediaan dan penyajiannya. Bahan pakan mengandung kadar air sehingga perlu diperhatikan agar tidak mengalami kerusakan yang cepat sejalan dengan waktu pemberiannya yang berlangsung tepat waktu. Pakan jenis buah-buahan mengandung kadar air tinggi. Kajian tahap pertama didapat kadar air pisang dan belimbing manis berturut-turut $\quad 72,44 \%$ dan $89,27 \%$, sedangkan daun-daunan dan jangkrik berturut-turut : daun matoa $67,10 \%$; daun kayu besi pantai $84,22 \%$; daun sawi hijau $88,63 \%$; daun kangkung $88,64 \%$ dan jangkrik $68,09 \%$. Tingginya kadar air dapat menyebabkan bahan pakan kuskus cepat mengalami kerusakan. Oleh karena itu perlu dikaji pengolahan pakan lebih lanjut.

Salah satu teknologi yang perlu diterapkan dalam pengolahan pakan yaitu 
memodifikasi bentuk pakan segar menjadi bentuk pakan olahan sehingga menjadi satu kesatuan yang utuh dalam bentuk ransum lengkap. Bentuk ransum lengkap yang telah mengalami pengolahan salah satunya ransum bentuk pelet. Ransum pelet dibuat melalui proses pengeringan bahan pakan segar (bahan baku) kemudian dilanjutkan dengan penggilingan dan dibentuk menjadi padat dalam bentuk pelet dengan ukuran tertentu. Pengolahan bahan baku menjadi pelet ditetapkan kadar airnya dan dilanjutkan melalui proses pengolahan secara mekanik (McEllhiary, 1992) yang sesuai dengan keperluan kadar nutrien dari ternak khususnya kuskus.

Ransum bentuk pelet telah dikenal dalam bidang peternakan karena ransum tersebut telah diaplikasikan pada ternak unggas broiler, kelinci dan ternak babi. Kajian Mulia (2009) dengan penambahan daun ubi jalar dan bungkil kelapa sawit dalam pengolahan ransum pelet untuk kelinci memberi nilai efisiensi ransum lebih baik dibanding bentuk mesh. Selain itu Nugroho et al. (2012) melaporkan bahwa kelinci yang diberi ransum pelet lebih tinggi tingkat palatabilitasnya $(26,2 \pm 0,58 \mathrm{~g} \mathrm{BK} / \mathrm{kg}$ bobot badan/hari) dibanding bentuk mesh (14,92 $\pm 10,33 \mathrm{~g} \mathrm{BK/bobot} \mathrm{badan/hari).}$

Namun dalam pengolahan bahan baku pakan menjadi bentuk pelet perlu diperhatikan fornulasi bahan penyusun ransum berdasar komposisi kimia dan spesifikasi pelet yaitu ukuran diameter cetakan pelet (Behnke, 2001). Ukuran pelet ransum pelet kelinci yang dilaporkan FAO (2008) diperoleh hasil bahwa ukuran 5mm menunjukkan konversi ransum dan pertambahan bobot badan lebih baik daripada ukuran $2,5 \mathrm{~mm}$ dan $7 \mathrm{~mm}$, sedangkan $7 \mathrm{~mm}$ lebih baik terhadap konsumsinya.

Selain uji palatabilitas dan konversi ransum yang telah dicapai akan lebih lengkap dengan adanya uji sifat fisik dari ransum pelet. Hal ini berkaitan dengan kualitas fisik dari ransum pelet yang berhubungan dengan daya simpan dan tidak mudah rusak dalam proses pengemasan atau pengangkutan bila berlanjut dalam level industri pakan.
Kualitas fisik ransum pelet mencakup : kadar air, aktivitas air, densitas pelet, densitas mesh, rasio ekspansi, ketahanan terhadap benturan dan ketahanan terhadap gesekan.

Ransum pelet fase starter untuk broiler memiliki ukuran diameternya $3 \mathrm{~mm}$ menunjukkan aktivitas air 0,8\% dan kerapatan tumpukan 98-98,92\% (Retnani et al., 2011). Aktivitas air menentukan tingkat kerusakan karena pada nilai aktivitas air 0,60,7 menunjukkan tumbuhnya kapang dan bakteri pada aktivitas air 0,9. Cara menurunkan aktivitas air sampai 0,6 adalah salah satunya dengan menambahkan suatu senyawa yang mampu mengikat air diantaranya gula (Mousir, 2014). Pisang mengandung kadar gula yang tinggi yang ditunjukkan dengan kadar karbohidrat 60,78\% (Adeolu et al., 2013). Selain itu pelet yang mempunyai daya serap air tinggi akan mudah hancur dan tidak tahan terhadap penyimpanan (Krisnan dan Ginting., 2009). Kajian Juniyanto et al. (2015) memperlihatkan bahwa kadar pati yang tinggi mampu memberi densitas pelet yang tinggi pula. Hal ini juga dilaporkan Akbar et al. (2017) bahwa diameter cetakan pelet $5 \mathrm{~mm}$ mampu menyebabkan ransum pelet tahan terhadap tumpukan rata-rata $0,67 \mathrm{~g} / \mathrm{ml}$.

Oleh karena perlu dilakukan kajian sifat fisik ransum pelet yang dibuat dari bahan-bahan pakan kuskus berdasar tingkat kesukaannya dari tahap penelitian pendahuluan, kemudian dimodifikasi dengan ukuran diameter pelet yang berbeda yaitu 5 $\mathrm{mm}$ dan $7 \mathrm{~mm}$.

\section{MATERI AND METODE}

\section{Tahap Persiapan}

Tujuh jenis bahan pakan kuskus sebagai bahan penyusun ransum pelet terdiri dari pisang mas (Musa paradisiaca var mas), belimbing manis (Averhoa carambola), daun matoa (Pometia pinnta), daun kayu besi pantai (Pongamia pinnata), daun kangkung (Ipomoea aquatica), daun sawi hijau (Brassiaca rapa var parachinensis) dan jangkrik (Gryllus sp).

Alat yang digunakan meliputi : oven, mesin giling, blender, mesin pelet manual, 
alumunium, seperangkat alat uji kualitas fisik pelet.

\section{Tahap pembuatan pelet}

Bahan pakan kuskus terdiri dari 7 jenis pakan segar : pisang mas, belimbing manis, daun matoa, daun kayu besi pantai, daun sawi hijau, daun kangkung dan jangkrik dilakukan pengeringan dengan menggunakan oven dalam suhu $60^{\circ} \mathrm{C}$. Setelah mengalami proses pengeringan selanjutnya dilakukan proses penggilingan menggunakan mesin giling dan blender. Bahan pakan yang telah digiling selanjutnya dicampur berdasar formulasi yang berbeda yaitu sebanyak 3 formulasi (A, B, dan C). Komposisi bahan pakan dan komposisi nutrien masing-masing formulasi ransum pelet disajikan pada Tabel 1 dan 2. Formulasi A diperoleh dari kajian penelitian tahap pendahuluan yaitu tingkat kesukaan kuskus terhadap 7 jenis pakan segar yang diberikan menggunakan sistem cafeteria feeding (Rodriguez et al., 2007), sedangkan formulasi $\mathrm{B}$ dan $\mathrm{C}$ didasari dengan meningkatkan protein dari kebutuhan (10\% untuk formulasi B dan 20\% untuk formulasi C) yang perhitungannya menggunakan program mikrosoft excel (ME), sebaliknya kadar pisang mas diturunkan
(Tabel 1). Kadar pisang mengandung gula tinggi yang juga berfungsi sebagai perekat.

\section{Metode Penelitian}

Masing-masing formulasi selanjutnya dicetak menjadi bentuk pelet dengan ukuran diameter $5 \mathrm{~mm}$ dan $7 \mathrm{~mm}$, sehingga menjadi 6 jenis ransum bentuk pelet yaitu :

1. Formulasi A dengan ukuran diameter pelet $5 \mathrm{~mm}$.

2. Formualsi A dengan ukuran diamaeter pelet7 $\mathrm{mm}$

3. Formulasi B dengan ukuran diameter pelet $5 \mathrm{~mm}$

4. Formualsi B dengan ukuran diameter pelet $7 \mathrm{~mm}$

5. Formulasi $\mathrm{C}$ dengan ukuran diameter pelet $5 \mathrm{~mm}$

6. Formulasi $\mathrm{C}$ dengan ukuran diameter pelet $7 \mathrm{~mm}$

Data yang diperoleh dianalisis sidik ragam terhadap kadar air, aktivitas air, densitas pelet dan densitas mesh dengan menggunakan rancangan acak lengkap yang diulang 3 kali untuk masing-masing perlakuan, sedangkan untuk pengujian ketahanan terhadap gesekan dan benturan dianalisis secara deskriptif.

Tabel 1. Komposisi bahan pakan dan nutrien ransum bentuk pelet

\begin{tabular}{lccccccc}
\hline \multirow{2}{*}{ Perlakuan } & \multicolumn{7}{c}{ Komposisi bahan pakan (\%) } \\
\cline { 2 - 8 } & $\begin{array}{c}\text { Pisang } \\
\text { Mas }\end{array}$ & $\begin{array}{c}\text { Belimbing } \\
\text { manis }\end{array}$ & $\begin{array}{c}\text { Daun } \\
\text { matoa }\end{array}$ & $\begin{array}{c}\text { Daun kayu } \\
\text { besi pantai }\end{array}$ & $\begin{array}{c}\text { Daun } \\
\text { sawi hijau }\end{array}$ & $\begin{array}{c}\text { Daun } \\
\text { kangkung }\end{array}$ & Jangkrik \\
\hline A-5 mm & 84,34 & 7,48 & 3,21 & 1,55 & 1,72 & 1,28 & 0,42 \\
A-7 mm & 84,34 & 7,48 & 3,21 & 1,55 & 1,72 & 1,28 & 0,42 \\
B-5 mm & 81,20 & 4,10 & 3,00 & 5,10 & 2,10 & 4,20 & 0,30 \\
B-7 mm & 81,20 & 4,10 & 3,00 & 5,10 & 2,10 & 4,20 & 0,30 \\
C-5 mm & 77,10 & 4,10 & 3,90 & 3,90 & 4,60 & 6,10 & 0,30 \\
C-7 mm & 77,10 & 4,10 & 3,90 & 3,90 & 4,60 & 6,10 & 0,30 \\
\hline
\end{tabular}

Keterangan :Formulasi ransum diperoleh dari penelitian pendahuluan; PK=protein kasar; SK=serat kasar; LK=lemak kasar; BETN=bahan ekstrak tanpa Nitrogen. 
Tabel 2. Komposisi nutrien ransum pelakuan

\begin{tabular}{lcccccc}
\hline \multirow{2}{*}{ Perlakuan } & \multicolumn{6}{c}{ Komposisi nutrien } \\
\cline { 2 - 6 } & $\begin{array}{c}\text { Protein } \\
\text { kasar (\%) }\end{array}$ & $\begin{array}{c}\text { Serat } \\
\text { kasar }(\%)\end{array}$ & $\begin{array}{c}\text { Lemak } \\
\text { kasar }(\%)\end{array}$ & $\begin{array}{c}\text { BETN } \\
(\%)\end{array}$ & Abu (\%) & Energi (kkal/kg) \\
\hline A-5mm & 7.67 & 6,11 & 1,43 & 77,9 & 6,89 & 2811,94 \\
A-7mm & 7,67 & 6,11 & 1,43 & 77,9 & 6,89 & 2811,94 \\
B-5mm & 8,79 & 6,57 & 1,42 & 76,18 & 7,22 & 2820,32 \\
B-7mm & 8,79 & 6,57 & 1,42 & 76,18 & 7,22 & 2820,32 \\
C-5mm & 9,65 & 6,57 & 1,42 & 74,58 & 7,49 & 2824,71 \\
C-7mm & 9,65 & 6,57 & 1,42 & 74,58 & 7,49 & 2824,71 \\
\hline
\end{tabular}

\section{Peubah yang Diamati}

Peubah yang diamati meliputi : Kadar air (AOAC; 2005), aktivitas air (Syarief dan Halid, 1993), densitas pelet (USDA, 1999), densitas mesh (Khalil, 1999), ketahanan terhadap gesekan (metode Pfost tumbling) dan ketahanan terhadap benturan (Balogopalan et al., 1988).

\section{HASIL DAN PEMBAHASAN}

Hasil penelitian uji kualitas fisik ransum pelet yang terdiri dari tujuh jenispakan kuskus disajikan pada Tabel 3.

\section{Kadar Air}

Pada Tabel 3 terlihat bahwa hasil analisis dari pengukuran kadar air ransum pelet menunjukkan kisaran 4,94-7,94\%. Setelah analisis sidik ragam ternyata tidak menunjukkan pengaruh nyata $(\mathrm{P}>0,05)$ terhadap kadar air antara 6 perlakuan ransum pelet. Hal ini disebabkan bahan penyusun ransum pelet sama dengan kisaran kadar bahan kering yang relatif sama yaitu pada kisaran 89,37 - 96,77\%. Kadar air yang terkandung dalam 6 kombinasi ransum pelet berada pada kisaran yang tidak melebihi dari 13-14\%. Semakin rendah kadar air menyebabkan kualitas pelet lebih baik (Saenab et al., 2010), karena tidak menyebabkan tumbuhnya bakteri, kapang dan sebagainya (Mousir, 2014). Selain itu pula kadar air mempengaruhi daya penyimpanan ransum pelet yang berhubungan langsung dengan mutunya (Retnani et al., 2009).

\section{Aktivitas Air}

Pada Tabel 3 terlihat bahwa ransum pelet yang diformulasi dari 7 jenis pakan menunjukkan perbedaan sangat nyata $(\mathrm{P}<0,01)$ antara 6 kombinasi ransum pelet. Aktivitas air dari 6 kombinasi ransum pelet ternyata terendah 0,55 pada perlakuan A-7 $\mathrm{mm}$ dan tertinggi pada perlakuan B-7 mm dan C-5 mm yaitu 0,66 . Namun dari semua perlakuan ternyata perlakuan A sangat baik karena nilai aktivitas airnya berada tidak melebihi dari 0,6-0,7.

Tabel 3. Kualitas fisik ransum pelet yang diformulasi dari tujuh jenis pakan kuskus

\begin{tabular}{lcccccc}
\hline \multirow{2}{*}{ Perlakuan } & \multicolumn{7}{c}{ Kualitas fisik ransum pelet } \\
\cline { 2 - 7 } & KA $(\%)$ & AA $(\%)$ & DP $(\mathrm{g} / \mathrm{cm} 3)$ & DM $(\mathrm{g} / \mathrm{cm} 3)$ & KTG $(\%)$ & KTB $(\%)$ \\
\hline A-5mm & $7,94 \pm 1,99$ & $0,57 \mathrm{ab} \pm 0,08$ & $0,47 \mathrm{~b} \pm 0,03$ & \multirow{2}{*}{$0,571 \mathrm{~b} \pm 0,01$} & 96,8 & 98 \\
A-7mm & $4,94 \pm 1,19$ & $0,55 \mathrm{a} \pm 0,08$ & $0,43 \mathrm{~b} \pm 0,01$ & & 96,2 & 99 \\
B-5mm & $7,86 \pm 4,98$ & $0,64 \mathrm{~b} \pm 0,08$ & $0,48 \mathrm{bc} \pm 0,01$ & $0,571 \mathrm{~b} \pm 0,01$ & 96,1 & 99 \\
B-7mm & $5,76 \pm 0,18$ & $0,66 \mathrm{~cd} \pm 0,02$ & $0,36 \mathrm{a} \pm 0,01$ & & 93,7 & 98 \\
C-5mm & $5,53 \pm 1,91$ & $0,66 \mathrm{~cd} \pm 0,03$ & $0,42 \mathrm{ab} \pm 0,003$ & $0,488 \mathrm{a} \pm 0,01$ & 94,7 & 98 \\
C-7mm & $6,95 \pm 1,15$ & $0,63 \mathrm{~b} \pm 0,04$ & $0,35 \mathrm{a} \pm 0,01$ & & 90,5 & 99 \\
\hline
\end{tabular}

Keterangan : KA = kadar air; $\mathrm{AA}=$ aktivitas air; $\mathrm{DP}=$ densitas pelet; $\mathrm{DM}=$ densitas mesh; KTG=ketahanan terhadap gesekan; KTB=ketahanan terhadap benturan.

11 | Kajian kualitas fisik ransum pelet upaya rekayasa ransum bagi kuskus...(Kayadoe et al., 2020) 
Hal ini sesuai dengan yang dikemukakan Mousir (2014) bahwa kadar gula yang tinggi dapat menurunkan daya ikat air. Pada perlakuan A menggandung pisang mas dengan prosentase lebih tinggi dibanding perlakuan $\mathrm{B}$ dan $\mathrm{C}$, sehingga aktivitas air pada perlakuan A lebih rendah dibanding perlakuan lainnya. Oleh karena itu perlakuan A memungkinkan untuk tidak ditumbuhi bakteri maupun kapang.

Nilai aktivitas air berkaitan dengan daya simpan bahan pakan (Balitz et al., 2009) termasuk ransum pelet. Penurunan aktivitas air melalui proses pengeringan (Leviana dan Paramitha, 2017) dan adanya kadar gula dalam pakan. Selain tingginya kadar gula yang terkandung di dalam pisang, juga ada dalam belimbing manis (Rachmiyati et al., 2017), sehingga berpengaruh terhadap aktivitas air. Pisang mas dan belimbing yang terdapat dalam ransum perlakuan A lebih tinggi dibanding ransum $\mathrm{B}$ dan $\mathrm{C}$, sehingga aktivitasnya pada perlakuan A lebih rendah.

\section{Densitas Pelet}

Pada Tabel 3 tersaji bahwa densitas pelet dari 6 perlakuan menunjukkan pengaruh sangat nyata $(\mathrm{P}<0,01)$ yaitu tertinggi pada perlakuan B-5 mm, sedangkan densitas terendah pada perlakuan C-7 mm. Grafik 1 terlihat bahwa densitas ransum pelet yang mempunyai diameter pelet $5 \mathrm{~mm}$ lebih tinggi dibanding $7 \mathrm{~mm}$. Hal ini menunjukkan bahwa diameter pelet yang semakin besar menyebabkan kerenggangan sehingga kekompakan bahan semakin kecil seperti yang terjadi pada ransum pelet berdiameter 7 $\mathrm{mm}$. Sesuai dengan pendapat Balagopalan et al. (1998) bahwa kualitas pelet dipengaruhi oleh ukuran diameter pelet. Hasil kajian Akbar et al. (2017) ternyata diameter pelet 5 $\mathrm{mm}$ dapat mempertahankan kerapatan tumpukan rata-rata $0,67 \mathrm{~g} / \mathrm{ml}$.

\section{Densitas Mesh (Campuran Bahan Penyusun Ransum Pelet)}

Pada Tabel 3 terlihat bahwa 3 formulasi mesh berbeda sangat nyata $(\mathrm{P}<0,01)$ yaitu terendah pada formulasi $\mathrm{C}$ yaitu $\left(0,488 \mathrm{~g} / \mathrm{cm}^{3}\right)$. Perlakuan $\mathrm{C}$ merupakan campuran yang ditingkatkan kadar proteinnya namun serat kasarnya tinggi pula dan prosentase pisang paling sedikit $(77,10 \%)$ dengan $\mathrm{B}$ dan $\mathrm{A}$ seperti terlihat pada Grafik 2.

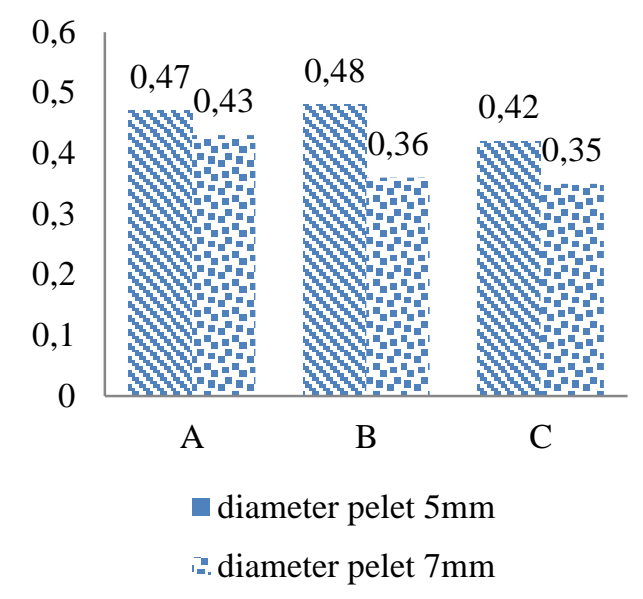

Grafik 1. Densitas pelet berdasar diameter pelet $5 \mathrm{~mm}$ dan $7 \mathrm{~mm}$

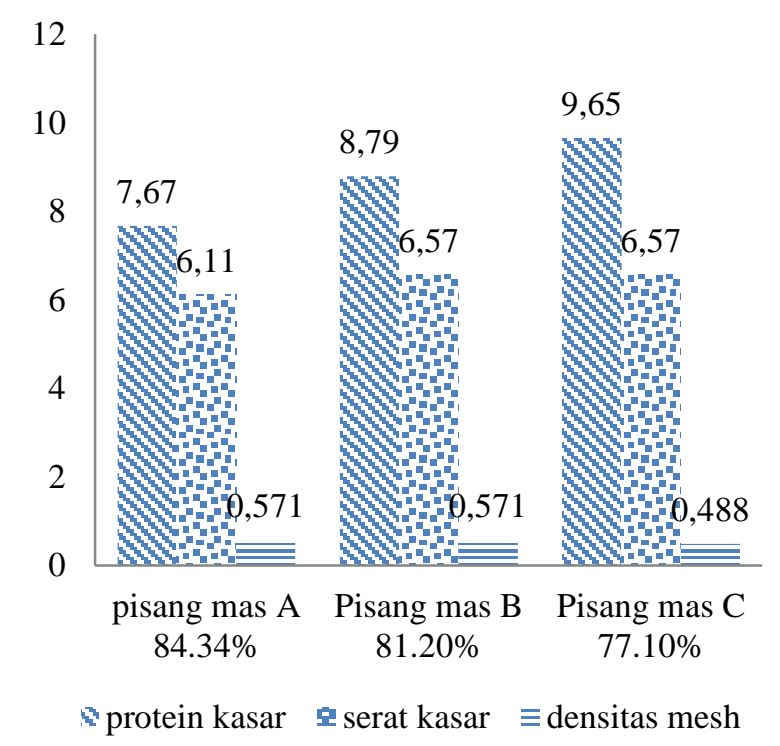

Grafik 2. Keterkaitan kadar pisang, protein kasar dan serat kasr terhadap densitas mesh.

Tinggi rendahnya prosentase pisang dapat mempengaruhi daya rekatnya, sehingga berpengaruh terhadap densitas mesh. Bila dibandingkan dengan ransum ayam broiler yang memiliki densitas $608-632 \mathrm{~kg} / \mathrm{m}^{3}$ $\left(0,608-0,632 \mathrm{~g} / \mathrm{cm}^{3}\right)$ ternyata densistas mesh hasil dari formulasi buah-buahan, daun- 
daunan dan jangkrik masih lebih rendah namun masih berada di atas standar $\left(0,450 \mathrm{~g} / \mathrm{cm}^{3}\right)$.

\section{Ketahanan Ransum Pelet terhadap Gesekan}

Pada Tabel 3 tersaji bahwa ketahanan terhadap gesekan pada 6 ransum pelet ternyata dengan kisarann di atas 90\% termasuk ransum pelet yang tahan terhadap gesekan. Hal ini diduga karena adanya pisang dalam formulasi ransum selain sebagai salah satu bahan pakan juga sebagai perekat. Adanya kandungan gula yang tinggi $(60,87 \%)$ menyebabkan daya rekat semakin kuat. Nilai ketahanan terhadap gesekan pada ransum pelet termasuk katagori tinggi yaitu $>80 \%$, karena yang dikemukakan Tabil dan Sokhansanj (1996) bahwa bila durabilitas pelet $<70 \%$ termasuk katagori rendah, 70$80 \%$ katagori sedang dan $>80 \%$ katagori tinggi.

Perbedaan pelet $(5 \mathrm{~mm}$ dan $7 \mathrm{~mm})$ terahdap ketahanan terhadap gesekan pada 6 ransum pelet terlihat pada Grafik 3 .

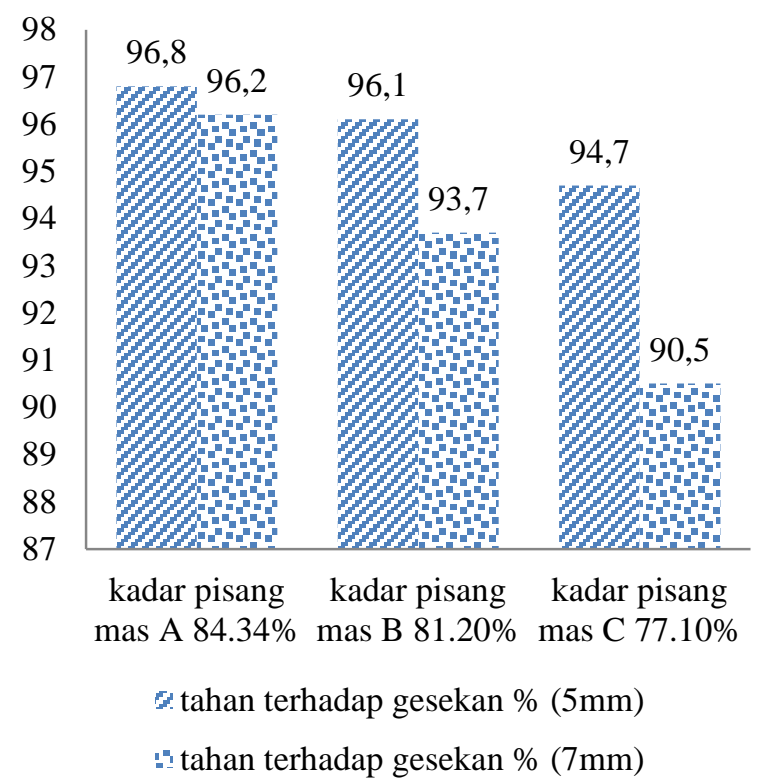

Grafik 3. Ketahanan terhadap gesekan pada ransum pelet dengan diameter pelet yang berbeda.

Pada Grafik 3 terlihat bahwa ransum pelet yang mengandung bahan pakan pisang lebih banyak menunjukkan lebih tahan terhadap gesekan. Sesuai dengan hasil kajian
Ismi et al. (2017) ternyata penambahan molasses $7 \%$ (pada pelet lebih tanahn terahadap gesekan daripada pelet yang diberi molasses hanya 5\% dan 3\%. Selain itu di antara ukuran diameter pelet yang berbeda ternyata ransum pelet yang memiliki ukuran diameter pelet $5 \mathrm{~mm}$ lebih tahan terhadap gesekan. Hal ini menunjukkan bahwa daya rekat yang diperoleh dari pisang lebih kuat pada ukuran pelet yang lebih kecil. Sesuai dengan yang dikemukakan Balagopalan et al, (1988) dan Ismi et al. (2017) bahwa kekompakan dan daya kuat pelet juga tergantung pada ukurran pencetak pelet selain jenis pakannya.

\section{Ketahanan ransum pelet terhadap benturan}

Pada Tabel 3 telihat 6 jenis ransum pelat memiliki ketahanan terhadap benturan 98-99\%. Nilai ini mendkati sama dengan pelet yang diberi perekat solid-ex-decander yaitu 97,12-97,95\% (Krisnan dan Ginting, 2009), pelet yang diberi daun mengkudu juga pada kisaran 97,77-98,28\% (Akbar et al., 2017) dan pelet yang diberi perekat onggok yaitu 98,72-99,73\% (Retnani et al., 2011).

Ketahanan terhadap benturan pada ransum pelet menunjukkan kemampuan ransum tersebut saat proses pengemasan maupun pengangkutan sebagai bentuk dari kualitas ransum pelet tersebut (Akbar et al., 2017). Namun dari beberapa kajian (Krisnan dan Ginting, 2009; Retnani et al., 2011; dan Akbar et al., 2017) ternyata tingkat ketahanan pelet sangat tergantung dari perekat. Pada ransum pelet yang diberi bahan pakan yang mengandung gula tinggi yaitu pisang dalam kajian ini ternyata mampu memberi daya tahan terhadap benturan yang mendekati sama dengan ransum yang diberi perekat berbeda.

\section{Penilaian Berdasar Skor}

Penilaian berdasar skor terhadap kualitas fisik ransum pelet yang diformulasi dari tujuh jenis pakan kuskus disajikan pada Tabel 4. 
Tabel 4. Penilaian kualitas fisik ransum pelet berdasar skor

\begin{tabular}{lccccccc}
\hline \multirow{7}{*}{ Perlakuan } & \multicolumn{7}{c}{ Kualitas fisik ransum pelet } \\
\cline { 2 - 8 } & $\begin{array}{c}\text { KA } \\
(\%)\end{array}$ & $\begin{array}{c}\text { AA } \\
(\%)\end{array}$ & $\begin{array}{c}\text { DP } \\
(\mathrm{g} / \mathrm{cm} 3)\end{array}$ & $\begin{array}{c}\mathrm{DM} \\
(\mathrm{g} / \mathrm{cm} 3)\end{array}$ & $\begin{array}{c}\text { KTG } \\
(\%)\end{array}$ & $\begin{array}{c}\text { KTB } \\
(\%)\end{array}$ & Rataan \\
\hline Diameter 5 mm : & & & & & & & \\
A-5 mm & 1 & 1 & 2 & 2 & 2 & 1 & $1,5=2$ \\
B-5 mm & 1 & 2 & 2 & 1 & 2 & 2 & $1,7=2$ \\
C-5 mm & 2 & 1 & 2 & 1 & 2 & 2 & $1,7=2$ \\
Rataan & 1,3 & 1,3 & 2 & 1,3 & 2 & 1,6 & $1,6=2$ \\
Diameter 7 mm : & & & & & & & \\
A-7 mm & 2 & 2 & 1 & 1 & 1 & 2 & $1,5=2$ \\
B-7 mm & 2 & 1 & 1 & 2 & 1 & 1 & $1,3=1$ \\
C-7 mm & 1 & 2 & 1 & 2 & 1 & 1 & $1,3=1$ \\
Rataan & 1,6 & 1,6 & 1 & 1,6 & 1 & 1,3 & $1,4=1$ \\
\hline
\end{tabular}

Keterangan : KA : kadar air; AA : aktivitas air; DP : densitas pelet; DM : densitas mesh; KTG : ketahanan terhadap gesekan; KTB : ketahanan terhadap benturan.

Berdasar Tabel 4 terlihat bahwa yang terbaik kualitas fisik pelet pada formulasi A baik pada diameter $5 \mathrm{~mm}$ maupun $7 \mathrm{~mm}$, namun bila dilihat berdasar perbedaan ukuran diameter pelet ternyata $5 \mathrm{~mm}$ lebih baik dibanding $7 \mathrm{~mm}$ untuk semua formulasi.

\section{KESIMPULAN}

Berdasarkan penilaian kualitas fisik terhadap 6 perlakuan ransum pelet dapat disimpulkan bahwa semua ransum pelet memiliki kualitas yang baik, karena kadar air, aktivitas air menjamin tidak mudah ditumbuhi bakteri atau kapang dan juga memiliki daya simpan dan tahan terhadap benturan dalam penumpukan atau pengangkutan. Namun dari 6 perlakuan ransum pelet yang terbaik pada formulasi $\mathrm{A}$ yaitu formulasi berdasar pada tingkat kesukaan tujuh bahan pakan oleh kuskus.

\section{UCAPAN TERIMAKASIH}

Kami mengucapkan terimakasih kepada : Pimpinan dan Dekan Fakultas Peternakan di Universitas Padjadjaran dan di Universitas Papua, serta Teknisi Laboratorium di Balai Penelitian Ternak Ciawi, Laboratorium Nutrisi dan Makanan Ternak Fakultas Peternakan Universitas Padjadjaran, Fakultas Peternakan Universitas Papua, Fakultas Peternakan Institut Pertanian
Bogor yang telah membantu guna terlaksananya penelitian ini. Terimakasih pula kepada Kementrian Riset dan Teknologi (No.1251.52/E4.4/2013) dan Propinsi Papua Barat yang telah memberi dukungan dana dalam pelaksanaan penelitian.

\section{DAFTAR PUSTAKA}

Adeolu, A. T. D.O. Enesi. 2013. Assesment of Proximate, Vitamine and Phytochemical Compositions of Plantae in Musa paradisiaca L. International Res. Jur. Of Plant Sci.4 (7) : 192-197.

Akbar, M. R. L., D. M. Suci, I. Wijayanti. 2017. Evaluasi Kualitas Pelet Pakan Itikyang Disuplementasi Tepung Daun Mengkudu (Marinda citrifolia) dan Disimpan selama 6 Minggu. Buletin Makanan Ternak. 104 (2) : 31-48.

AOAC (Association of Official Analytical Chemists. 2005. Official Methods of $\quad$ Analyisis. $16^{\text {th }}$ 
Ed.AOAC.International Washington DC.

Balagopalan, C., G. Padmaja, S. K. Nanda dan S. N. Moorthy. 1988. Cassava in Food, Feed and Industry. IRC Press. Florida.

Behnke, K. C. 2001. Proceesing Factor Influencing Pelet Quality. Feed Tech. 5 (4) : $1-7$.

Balitz, H. D., W. Grosch, P. Schieberle. 2009. Springer Food Chemistry $4^{\text {th }}$ Revised and Extended Edition Annual Review Biochemistry. 79 : 655-681.

Dahrudin, H., W. R. Farida., A. S. Rohman. 2005. Jenis-jenis Tumbuhan Sumber Pakan dan Tempat Bersarang Kuskus (Famili Phalangeridae) di Cagar Alam Biak Utara Papua. Jur. Biodiversitas. $6(4): 253-258$.

FAO. 2008. in Firegan dan Steven. 2008. Nutrition and Feeding: Melalui fao.org/docrep/t1690E/1690e04.htm.

Farida, W. R., Nurjaeni, R. Mutia, D. Diapari. 2004. Kemampuan Cerna Kuskus Beruang (Ailurops ursinus) Terhadap Pakan Alternatif di Penangkaran. J. Biosmart. 6 (1) : 6570. Melalui biosains.mipa.ac.id. (2015).

Farida. W. R., K. K. Wardani, A. S. Tjakradidjaja, D. Diapari. 2008. Konsumsi dan Penggunaan Pakan Pada Tarsius (Tarsius bancanus) Betina di Penangkaran. J. Biodiversitas. 9 (2) : 148-151.

Flannery, T. F. 1994. Mammals of New Guinea. Australian Museum. Revised and Updated Edition.

Ismi, R.S., R. I. Pujaningsih., S. Sumarsih. 2017. Pengaruh Penambahan level Molases terhadap Kualitas Fisik dan Organoleptik Pelet Pakan Kambing Periode Penggemukan. J. Ilmiah Peternakan Terpadu. 5 (3) : 58-62.
Juniyanto, M.I.R., I. Susilawati, H. Supratman. 2015. Ketahanan dan Kepadatan Pelet Hijauan Rumput Raja (Pennisetum purphoides) Dengan Penambahan Berbagai Dosis Bahan Pakan Sumber Karbohidrat. Jur.unpad.ac.id. Melalui : Beranda. 4 (2) : 1-13.

Kabelen, F., M. Warpur. 2009. Struktur Komposisi Jenis Pohon dan Nilai Ekologi Vegetasi Kawasan Hutan di Kampung Sewan Distrik Sarmi Kabupaten Sarmi. Jur. Bio. Papua.1 (2) : 72-80.

Kartikasari, S. N., A. J. Marshall., B. M. Beehler. 2013. Ekologi Papua. Pn. Yayasan obor. Indonesia. Jakarta.

Kayadoe, M., J. F. Koibur, H. Warmetan. 2014. Komposisi Kimia dan Komponen Serat Berbagai Jenis Pakan Lokal yang Berasal dari Habitat Asal Kuskus dan Penangkaran. J. Sains Peternakan. 12 (1) : 15-18.

Kayadoe, M., S. Sinaga, H. Warmetan, J. F. Koibur, H. Yumiarti, A. Rochana, U. H. Tanuwiria. 2015. Evaluasi Kebutuhan ZAt-zat Makanan Bagi Kuskus Bertotol (Spilocuscus maculatus) dalam Penangkaran Melalui Penggunaan Bahan Pakan Lokal. Pros. Seminar Nasional Peternakan Berkelanjutan. 7-11 Nopember 2015 : 319-324.

Khalil. 1999. Pengaruh Kandungan Air dan Ukuran Partikel terhadap Sifat Fisik Pakan Lokal : Kerapatan Tumpukan, Kerapatan Pemadatan Tumpukan dan Berat Jenis. Media Peternakan. 22 (1) : $1-11$.

Krisnan, R. dan S. P. Ginting. 2009. Penggunaan Solid-ex-decanter Sebagai Perekat Pembuatan Pakan Komplit Berbentuk Pelet: Evaluasi Fisik Pakan Komplit Berbentuk Pelet. Seminar Nasional Teknologi Peternakan dan Veteriner : 480-486. 
Leviana, W dan V Paramitha. 2017. Pengaruh Suhu terhadap Kadar Air dan Aktivitas Air dalam Bahan Pada Kunyit (Curcuma longa) dengan Alat Pengering Electrical Oven. Metana. $13(2)$ : 37-44.

McEllhiary, R. R. 1994. Feed Manufactoring Technology IV. American Feed Industry.Assoc. Inc. Arlington.(US).

Mousir. 2014. Aktivitas Air Bahan Pangan. https://www.pengolahan pangan.com/2016/11/Aktivitas air-aw bahan pangan.html.

Mulia. 2009. Penampilan Produksi Kelinci Potong Jantan Lokal yang diberi Ransum Komplit Mengandung Bungkil Inti Sawit Dengan Jenis HIjauan yang Berbeda. Fapet. IPB. Bogor.

Nakoh. O., P.I. Bumbut., M.S.E. Kilmaskossu. 2010. Forest Vegetation As The Cuscus Feeding Plants in Udopi Wosi Village Forest Complex, Manokwari District, Papua. Tigerpaper. 37(2): 26-28.

Nugroho, S.S., S.P.S. Budhi., Panjono. 2012. Pengaruh Penggunaan Konsentrat Dalam Bentuk Pelet dan Mesh Pada Pakan Dasar Rumput Lapangan terhadap Palatabilitas dan Kinerja Kelinci Jantan. Bul. Pet. 36 (3) : 169-173.

Rachmiyati, H., W. H. Susanto., J. M. Maligan. 2017. Pengaruh Tingkat Kematangan Buah Belimbing (Averhoa carambola L) dan Proporsi Penambahan Gula terhadap Karakterisitik Fisik Kimia dan Organoleptik Jelly Drink Mengandung Karaginan. J. Pangan dan Agroindustri. $\quad$ 5(1): 49-60. https://jpa.ub.ac.id/index.php/article/d owload/497/375.

Retnani, Y., W. Widiarti, I. Amiroh, L. Herawati, K. B. Satoto. 2009. Daya
Simpan dan Palatabilitas Wafer Ransum Komplit Pucuk dan Ampas Tebu Untuk Sapi Pedet. Media Peternakan. 32 : 130-136.

Retnani,Y., L. Herawati, dan S. Khusniati. 2011. Uji Sifat Fisik Ransum Broiler Starter Bentuk Crumble Berperekat Tepung Tapioka, Bentonit dan Onggok. Jurnal Ilmu dan Teknologi Peternakan 1(2): 88-97.

Rodriguez, A. B., R. Bodas, B. Fernandez., O. L-Campos, A. R. Mantecon., F. J. Giraldez. 2007. Feed Intake and Performance of Growing Lambs Raised on Concentrate Based Diets Under Cafetaria Feeding Systems. The Animal Consotium 2007 . Animal 1: 459-466.

Saenab, A., E. B. Laconi., Y. Retnani., M.S. Mas'ud. 2010. Evaluasi Kualitas Pelet Ransum Komplit yang Mengandung Produk Samping Udang. JITV.15 (1) : 31-39.

Saragih, E.W., M. J Sadsoeitoeboen, F. Pattiselanno. 2010. The Diets of Spotted Cuscus (Spilocuscus maculatus). Bio.Sci. 2 (2) : 78-83.

Sinaga, W., D.A. Iskandar, E. Wirdateti, J. Pamungkas. 2010. Konsumsi Pakan Asal Hewan pada Kukang (Nycticebus coucang) di Fasilitas Penangkaran. Pusat Studi Satwa Primata. Institut Pertanian Bogor. J. Primatologi Indonesia.7 (2) : 69-75.

Sinery, A.S., J. Manusawai, W.R. Farida. 2013. Population and Carrying Capacity of Cuscus in Tourist Island of Ahe. District of Nabire. Province of Papua. Intern. Journ. of Tropical Nature Sci.1 (1) : 19-23.

Sinery, S.A. 2015. The Managemen Strategy of Cuscus in the Numfor Island. Deepublish Yogyakarta (Indonesia). 
Syarief, R., H. Halid. 1993. Teknologi Penyimpanan Pangan. Pb. Arcan. Jakarta.

Tabil, L. Jr., S. Sokhansanj. 1996. Process Conditions Affecting The Physical Quality Of Alfalfa Pelet. Appl. Eng. Agric. 12 : 345-350.

USDA. 1999. Pratical Procedure For Grain Handlers : Inpectiny Grain. United States Departemen of Agriculture-
Grain Inspection. Packers and Stockyards Administration.

Wibisono, Y., R. Gatot, N. T. A. Kilmaskossu, P. A. Dimomonmau, F. J. Hutapea, M. Rumawak. 2018. Laporan Hasil Kegiatan Survei Populasi Habitat Kuskus di PT. Wijaya Sentosa, Kabupaten Teluk Wondama, Papua Barat. Verifikasi Jenis dan Keanekaragaman. 